\title{
The sustainable heritage environment in the Asian region
}

\author{
S. Y. Said \\ Universiti Teknologi MARA, Shah Alam, Malaysia
}

\begin{abstract}
Heritage cities in the Asian region including Malaysia currently face intensified urban problems as a result of rapid population growth, economic development and urbanisation. The government perceives the development of new townships as a solution to disperse population pressure from city centres and to cater for the growing population. However, new towns at the edge of historic cities were sterile, reflected the adaptation of poor urban design guidelines in creating harmony with the historic urban fabric. Many great cities in this region are undergoing this pressure for rapid development. The demolishing of many cultural built heritages is the result of a misunderstanding of the significance of the heritage. Urban conservation, viewed as the most relevant way to sustain historic cities, was to stay relevant and beneficial; historic cities have to catch up with the demand for a modern lifestyle. A good planning method is required to ensure that the old components will stay intact within the current environment. This paper will look at the urban conservation approach in Singapore as the benchmark for urban conservation in the region and compare with measures to protect urban heritage in Malaysia, Indonesia, and Hong Kong. Nonetheless, the differences in the geographical, political, economic and social characteristics of the countries were to be taken into account while analysing and proposing the best practice for urban conservation. Political aspiration, financial ability and social support from the area would determine the possibility of the success to sustain the heritage environment in this region.
\end{abstract}

Keywords: sustainable heritage, modern lifestyle, urban conservation.

\section{Introduction}

Rapid population growth, economic development and urbanization are three key elements faced by many historic cities in developing a nation especially in the 
South East Asian region. To disperse population pressure from city centres and to cater for the growing population, new townships were introduced. The pressure of development is higher in developing nations than in other places. It is the benchmark for success and how far society has evolved. Less consideration on the importance of heritage environment as part and parcel of the image of a nation resulted in the demolishing of many cultural built heritages. In many cases, great administrative cities that had been the image of the nation were being left derelict because of the relocation of the city population to a newly developed area. This has left many significant buildings unattended and neglected.

Urban conservation is viewed as the most relevant way to sustain historic cities [1]. To stay relevant and beneficial, historic cities have to catch up with modern, new cities in forms of physical and economic attractions. In order to do so, a good planning method is required to ensure that the historic components will stay intact within the modern environment. One of the best ways to conserve urban heritage is by regeneration.

Most historic buildings can still be put to good economic use in, for example, commercial or residential occupation. The success of building conservation practice in the UK has been a great inspiration to many countries. Acts and policies used in the UK are often adopted and incorporated into local systems in countries such as, Singapore, Hong Kong, Indonesia and Malaysia. Nonetheless, due to the Eastern cultural and religious beliefs, the approaches to conservation are different. Southeast Asian practitioners in built heritage conservation confront many conservation challenges because of culture, political aspiration and customs.

According to Pickard [2], governments can encourage conservation, restoration and rehabilitation process in two ways: 'the first involves policies and measures to stimulate the private sector to invest in architectural heritage (the dynamic approach). The second derives from the fact that, without government support, the private sector may decide that investment is not economically justified, thus creating the need for financial incentives and subsidies (the support approach)'. Evidence from heritage-led regeneration scheme suggests that partnership programmes can generate six time or more of the initial public investment through the private sector partners or other sources [2]. Thus, partnership scheme should be introduced and considered in urban conservation and regeneration projects in Malaysia, to guarantee commitments from the public and private sectors in sustaining their built heritage.

Cultural heritage is the foremost consideration in the principles of historic conservation; hence the cultural, spiritual and religious aspects of the area are considered in most of the conservation work. This is not only in the conservation of religious and cultural monuments, but also in urban conservation practice. The Hoi An Protocol, the Nara Documents on Authenticity and the Xi'an Declaration which clearly underline all these factors are constantly referred to in the conservation of historic buildings, monuments and areas in Southeast Asia, alongside the international charters such as the Venice Charter and the Burra Charter. 
In the Hoi An Protocol the experts noted that the unaddressed threats from development and modernism have too often resulted in negative consequences to heritage sites such as [3].

- Dismemberment of heritage sites, with resultant loss of integrity;

- Dilapidation and structural deterioration of the fabric of the region's built environment to the point where it can no longer adequately support the human uses for which it is intended;

- Replacement of original components with counterfeit and nonindigenous technologies and materials;

- Loss of the sense of place of the region's heritage sites, through inappropriate reconstruction processes which homogenize their unique characteristics;

- Disenfranchisement of heritage from the traditions of community use.

The conclusion from the findings are that the heritage in Asia is in long-term danger because of inadequate public understanding of the need to conserve and inadequate localization of stewardship responsibility over heritage resources that has led to the above mistakes [3].

Many conservation projects in the Asian regions focus on individual buildings, mostly significant religious buildings such as the temple complexes of Angkor Wat in Cambodia, and Prambanan and Borobudur temple complexes in Indonesia. Area conservation remained largely ignored until recently, despite many efforts to save historic areas from degradation. The rapid transformation in urban fabric in many of the cities in the region has resulted in contentious issues relating to prioritising conservation that have gained prominence in most planning agendas in many Third World cities [4]. The growing realisation of the importance of preserving heritage in all forms in the midst of rapid modern development contributes to this situation. Successful urban conservation schemes can be seen in Singapore and Hong Kong, for example, where many parts of the urban area have experienced transformation.

However, the durability of the materials of traditional vernacular architecture does affect the survival of the historic buildings in the region. Most of the vernacular buildings in the Asian region were made from timber and thatch, and the most common problem of timber buildings are caused by climatic condition, fungal rots, insect infestation and termite attack [5]. These factors had caused the discontinued existence of many traditional buildings in the region. Many historic buildings that could still be found in this region were built of stone and bricks. This factor has also contributed to the streetscape of the cities.

\subsection{Urban conservation in Singapore}

Singapore introduced urban renewal schemes in 1964. The schemes focused on the development of public housing and residential estates. However, extensive redevelopment schemes were criticized for the demolition of the old shop house environment which is considered the architectural identity of the republic (Dale 
[6]). In response to that, the Urban Redevelopment Authority (URA) was established in 1974 in which one of the main objectives is towards the preservation of Singapore's historical and architectural heritage [4]. Nevertheless, the URA's conservation policies were not in any way translated into action in those early years where the agenda of redevelopment excluded the idea of conservation.

Fortunately, a major shift of policy occurred in 1976 when the URA initiated studies involving the conservation and rehabilitation of whole areas. In 1986, the Conservation Master Plan was made known to the public. The plan covers 100ha of old Singapore including Chinatown, Singapore River, Little India and Kampong Glam, the Civic and Cultural District and Emerald Hill. The conservation movement was the result of the need to preserve the shared values of heritage and tradition in the form of physical evidence, brought about by panic among the local politicians and historians from the infiltration of Western values, which had turned the society into a 'pseudo-Western' society [7]. Opportunely, it has saved most of Singapore's heritage and with good conservation work on the old buildings, has provided better living conditions for the inhabitants.

\subsection{Indonesia}

Nevertheless, neighbouring Indonesia maintained its approach to heritage conservation in a different manner compared to Singapore. Indonesia is moving towards modernisation, and conservation is considered as an elitist and antiprogress movement [8]. Therefore, urban conservation has not been considered in most of the development policies compared to cultural heritage conservation. The founding of the Indonesia Charter for Heritage Conservation in 2003 listed the importance of safeguarding both the natural and cultural heritage. Nevertheless, it fails to acknowledge the importance of safeguarding the built heritage in relation to its urban setting.

Indonesia, the world's fourth most populous country, is rich in diversified culture. Situated in Southeast Asia and Oceania region, the culture varies from one province to another. The country is known for the famous Hindu and Buddhist heritage of temples and Dutch colonialism architecture. Prambanan and Borobudur are the famous Hindu/Buddhist temple and among 16 sites inscribed under the World Heritage Lists.

\subsection{Hong Kong}

The Urban Renewal Authority supervises the redevelopment, rehabilitation, revitalisation and preservation of Hong Kong. The objectives of the agency are [9]:

(a) restructuring and re-planning designated target areas;

(b) designing more effective and environmentally-friendly local transport and road networks;

(c) rationalizing land uses;

(d) redeveloping dilapidated buildings into new buildings of modern standard and environmentally-friendly design;

(e) promoting sustainable development in the urban area; 
(f) promoting the rehabilitation of buildings in need of repair;

(g) preserving buildings, sites and structures of historical, cultural or architectural interest;

(h) preserving as far as practicable local characteristics;

(i) preserving the social networks of the local community;

(j) providing purpose-built housing for groups with special needs, such as the elderly and the disabled;

(k) providing more open space and community/welfare facilities; and

(l) enhancing the townscape with attractive landscape and urban design

This is in accordance with the strategy of an integrated planning and heritage conservation approach that was introduced under the Built Heritage Conservation Policy.

\subsection{Urban conservation in Malaysia}

Similar to neighbouring Singapore, the formation of government agencies responsible for the development of urban areas, which includes the plans for historic areas, started in the early 1970s [10]. In 1976, the Antiquity Act 168 was introduced. It focuses on the protection of ancient monuments and historical sites. The nature of the Act prescribes the safeguarding (control and preservation) of antiquities (ancient and historical monuments, archaeological sites and historical objects), and allows conservation to be carried out on monuments or buildings that the Department of Museums and Antiquities (Jabatan Muzium dan Antikuiti $(J M A))$ deems worthy of conservation and these are normally restricted to buildings and monuments that are more than 100 years old [11].

This was the 1976 Act that was formed solely to protect antiquities and national built heritage. Most parts of active conservation schemes in Malaysia are based on this Act. Prior to that, under the Urban Development Authority Act (1971) there were also considerations on the protection of historic buildings in developing urban areas, but without emphasis directly on the conservation of historic buildings and townships as the major subject.

The Antiquity Act has been the core for other planning, architecture and heritage protection acts at both national and state level. However, the limitations of the Act 168 have somehow restricted the selection of buildings to include only those that are public and highly significant in the context of historical and aesthetic value, avoiding those that are privately owned, even if they have merits equivalent to those other publicly owned buildings $[10,12]$. The reasons for this are simple: there were inadequate measures to cover the conservation of these buildings because the provisions in the Act 168 limit the process of intervention by the authorities on private properties and also because of the unwillingness of property owners to play any role in conserving their properties as part of the country's rich cultural legacy.

Another relevant act is the Town and Country Planning Act 1976 (Act 172) which empowers local authorities to prepare Local and Action Area Plans and the Designation of Conservation Districts following the completion of the Structure Plan of Urban Areas in the country [12]. The rules and procedures have to be 
worked out to identify buildings to be listed and the responsibilities delegated are not clear. This has resulted in a conflict in the implementation of the regulations.

The foremost act is the National Heritage Act 2005 (NHA2005). It replaced the Antiquity Act and is considered as the most practical and up to date act for heritage conservation in Malaysia. It was formed by taking into consideration international charters and policies such as the Burra Charter, the Hoi An Protocol and the Nara Documents of Authenticity. The act provides for the conservation and preservation of national heritage, natural heritage, tangible and intangible cultural heritage, underwater cultural heritage, treasure trove and related matters. It received Royal Assent on 30 December 2005 and was published in the Gazette on 31 December 2005. The National Heritage Act 2005 came into effect on 1 March 2006 [13, 14].

Studies from the research on conservation practices and heritage preservation in Malaysia, carried out by local academicians, indicate that there are no suggestions of acts and regulation used concerning heritage before Independence in 1957. During British colonisation, Malaya at that time used English Common Law. However, looking at the state of the old colonial administrative buildings found in most historic cities in Malaysia, there is evidence of maintenance and conservation work that helped to prolong the age of the buildings.

The implementation of NHA in 2005 was described by local conservationists and heritage trusts as too late to save much of Malaysia's built heritage. The demolition and abandonment of many important buildings has led to severe heritage loss. However, it does give hope for a brighter future for current great buildings and cities such as the Petronas Twin Towers, Kuala Lumpur Tower, Kuala Lumpur Sentral, Federal Government Administrative Centre Putrajaya, Cyberjaya mentioned above; and many more. The listing of Malacca and Georgetown in Penang as a World Heritage Site on $7^{\text {th }}$ July 2008 has also given a glimpse of a better future for Malaysia's historic built heritage [15].

NHA 2005 provides a clear definition of conservation as a process that includes preservation, restoration, reconstruction, rehabilitation and adaptation or any combination of these $[13,16]$. The act introduces the appointment of a Commissioner of Heritage who is responsible for the conservation of the national heritage. The Commissioner receives advice from the National Heritage Council whose members are the heads of multi-disciplinary agencies such as Town and Country Planning, Museum and Antiquity, Tourism and academicians.

Among the most important aspects of the NHA2005 is the formation of a Heritage Fund where money from government funds, gifts, grants and repayments is the source for any conservation work supervised by the Council. The Act introduces a comprehensive mechanism of protecting the heritage with the formation of a National Heritage Register, Monument Preservation Orders and Conservation Management Plans.

It is yet to be ascertained whether this Act has contributed to the improvement of the building conservation scenario in Malaysia. Historic states such as Malacca and Penang have their own Plans for Conservation Areas based on the Town and Country Planning Act 1995, the Antiquity Act 1976 and the adaptation of policies and laws concerning urban conservation from the UK, which pre-date the Act [13, 16]. Nevertheless, building conservation in Malaysia is highly influenced by 
political decisions. This has become a big barrier to ensure the survival of historic buildings. Some buildings were left neglected and some were demolished because of biased political decisions. Nonetheless, some religious buildings such as the Hindu and Buddhist Temples are safe due to the awareness of their believers who privately fund the repair and maintenance of their buildings.

Apart from that, the quest for national identity sees that new architectural style buildings are built to represent new Malaysian architecture. The mixture of Eastern and Western architecture is preferred in most of the new development; some are even a pastiche representation of the past. Some pre-war buildings are being demolished to give way to this new style. Consequently, building conservation is not a priority in the Malaysian building industry, regardless of the implementation of the National Heritage Act.

\section{Findings}

Table 1 compares heritage conservation in three countries in Southeast Asia. It shows the different levels of approach to conservation that have been influenced by the political and cultural circumstances of each country. Malaysia, although located in the same region, with similar historical, religious and cultural experiences of the countries, has its own approach to conservation as discussed above.

Table 1: A comparison of heritage conservation in Singapore, Hong Kong and Indonesia $[8,9,17]$.

\begin{tabular}{|c|c|c|c|}
\hline & Singapore & Hong Kong & Indonesia \\
\hline $\begin{array}{l}\text { Responsible } \\
\text { bodies }\end{array}$ & $\begin{array}{l}\text { Ministry of Information, } \\
\text { Communication and Arts } \\
\text { - Preservation of } \\
\text { Monument Board } \\
\text { Ministry of National } \\
\text { Development - Urban } \\
\text { Redevelopment Authority }\end{array}$ & $\begin{array}{l}\text { Culture, Leisure and } \\
\text { Sports Agency - } \\
\text { Antiquities and } \\
\text { Monuments Office } \\
\text { Urban Renewal } \\
\text { Authority (1999) } \\
\text { replacing Land } \\
\text { Development } \\
\text { Corporation }\end{array}$ & $\begin{array}{l}\text { Ministry of Culture and } \\
\text { Tourism (Departemen } \\
\text { Kebudayaan and } \\
\text { Pariwisata) } \\
\text { Heritage Indonesia Trust } \\
\text { (Badan Palestarian } \\
\text { Pusaka Indonesia) }\end{array}$ \\
\hline Guidelines & $\begin{array}{l}\text { - Conservation Master } \\
\text { Plan } 1986 \\
\text { - Urban Redevelopment } \\
\text { Authority Act } 1989 \\
\text { - Preservation of } \\
\text { Monuments Act } 1971 \\
\text { - Planning Act } 1998\end{array}$ & $\begin{array}{l}\text { Built Heritage } \\
\text { Conservation Policy } \\
\text { (submitted 2004, review } \\
\text { 2006) }\end{array}$ & $\begin{array}{l}\text { Indonesia Charter for } \\
\text { Heritage Conservation } \\
2003\end{array}$ \\
\hline Objectives & $\begin{array}{l}\text { To cater for the need } \\
\text { for new development to } \\
\text { position Singapore as a } \\
\text { modern } 21 \text { st century } \\
\text { business city, and }\end{array}$ & $\begin{array}{l}\text { - To conduct heritage } \\
\text { impact assessment for } \\
\text { new capital works } \\
\text { projects }\end{array}$ & $\begin{array}{l}\text { - Take up an active role } \\
\text { in heritage conservation } \\
\text { - Take immediate } \\
\text { measures to save } \\
\text { endangered heritage } \\
\text { from damage, ruin and } \\
\text { extinction }\end{array}$ \\
\hline
\end{tabular}


Table 1: Continued.

\begin{tabular}{|c|c|c|c|}
\hline & Singapore & Hong Kong & Indonesia \\
\hline Objectives & $\begin{array}{l}\text { - Planning and research } \\
\text { to extend the } \\
\text { knowledge on the } \\
\text { monuments } \\
\text { - Regulatory support to } \\
\text { guide restoration, } \\
\text { preservation and } \\
\text { protection of } \\
\text { monuments } \\
\text { - Outreach, to promote } \\
\text { and stimulate public } \\
\text { interest and support of } \\
\text { monuments } \\
\text { - Act as an advisory to } \\
\text { the government in } \\
\text { respect of matters } \\
\text { relating to the } \\
\text { preservation of } \\
\text { monuments }\end{array}$ & $\begin{array}{l}\text { - To implement the } \\
\text { Revitalising Historic } \\
\text { Buildings Through } \\
\text { Partnership Scheme } \\
\text { for Government- } \\
\text { owned historic } \\
\text { buildings } \\
\text { - To provide economic } \\
\text { incentives for } \\
\text { preservation of } \\
\text { privately-owned } \\
\text { historic buildings } \\
\text { - To provide financial } \\
\text { assistance for the } \\
\text { maintenance of } \\
\text { privately-owned } \\
\text { graded historic } \\
\text { buildings } \\
\text { - To set up a } \\
\text { Commissioner for } \\
\text { Heritage's Office } \\
\text { To take forward } \\
\text { heritage conservation } \\
\text { and revitalization } \\
\text { projects }\end{array}$ & $\begin{array}{l}\text { - Improve the capacity, } \\
\text { principles, processes, } \\
\text { and techniques of } \\
\text { conservation } \\
\text { appropriate to the } \\
\text { Indonesian context; } \\
\text { - Raise the awareness of } \\
\text { all parties on the } \\
\text { importance of heritage } \\
\text { conservation, through } \\
\text { education } \\
\text { - Raise institutional } \\
\text { capacity, develop } \\
\text { management systems, } \\
\text { as well as role- } \\
\text { - Expand networks of } \\
\text { cooperation and } \\
\text { develop resources } \\
\text { including means of } \\
\text { funding to support } \\
\text { heritage conservation; } \\
\text { - Reinforce legal } \\
\text { oversight, control, and } \\
\text { enforcement through } \\
\text { the development of } \\
\text { regulations } \\
\text { - Understand and } \\
\text { recognize the rights and } \\
\text { potentials of } \\
\text { marginalized people as } \\
\text { well as to assist and re- } \\
\text { empower the } \\
\text { community in the } \\
\text { conservation and } \\
\text { stewardship of their } \\
\text { heritage for sustained } \\
\text { prosperity. } \\
\end{array}$ \\
\hline $\begin{array}{l}\text { Approach to } \\
\text { conservation }\end{array}$ & $\begin{array}{l}\text { Area-based: urban } \\
\text { conservation } \\
\text { Adaptive re-use of } \\
\text { historic buildings } \\
\text { Implementation of 'old- } \\
\text { and-new' approach } \\
\text { Public-private } \\
\text { partnership in heritage } \\
\text { conservation } \\
\text { Integration of } \\
\text { conservation with urban } \\
\text { planning }\end{array}$ & $\begin{array}{l}\text { Monuments } \\
\text { conservation, however, } \\
\text { recently implemented } \\
\text { integrated urban } \\
\text { planning/conservation } \\
\text { under Urban Renewal } \\
\text { Authority; which } \\
\text { prioritized on urban } \\
\text { renewal }\end{array}$ & $\begin{array}{l}\text { Monument conservation } \\
\text { Moving towards } \\
\text { modernization, } \\
\text { Conservation of urban } \\
\text { area is considered as anti- } \\
\text { progress (development) }\end{array}$ \\
\hline
\end{tabular}




\section{Conclusion}

Looking at the studies of Malaysian's neighbours in the South East Asian Region, the act of conservation and preservation of heritage started in the early 1970s. The approaches towards the protection of heritage for the three countries were different. The governments of Singapore and Hong Kong focused on urban renewal schemes as solutions for their urban issues, while in Indonesia, 'conservation of the traditional historic urban areas was considered sentimental, irrational and even anti-progress' [8]. Indonesia, although rich in historical monuments which varied from religious archaeological legacy to colonial buildings, preferred monument conservation and promoted new development as solutions to urban issues [8].

In relation to this study, the integrated urban planning and building conservation schemes carried out in Hong Kong and Singapore are good examples to compare with the current policies and guidelines carried out for historic urban areas in Malaysia. The schemes have been shown to protect most of the historic core areas within the modern cities. On the other hand, the differences in the geographical, political, economic and social characteristics of the countries compared with Malaysia were to be taken into account while analysing and proposing the best practice for urban conservation in Malaysia. Nevertheless, being the closest neighbour, Malaysian approach to urban conservation is more likely similar to what Singapore has done. The only difference are the political aspiration, economic ability and social support from the area would determine the possibility of the success of the scheme.

\section{Acknowledgement}

The authors would like to thank the Universiti Teknologi MARA for the research grant. This review is a part of an undergoing research under Principle Support Initiatives Grants (PSI 300/2013).

\section{References}

[1] Said, S. Y. et al. (2013). Heritage Conservation and Regeneration of Historic Areas in Malaysia, Procedia Social and Behavioural Sciences 105, pp. 418-428, Elsevier

[2] Pickard, R. (2001). Policy and Law in Heritage Conservation. London: Spon

[3] UNESCO (2001). Hoi An Protocols for Best Conservation Practice in Asia. Professional guidelines for assuring and preserving the authenticity of heritage sites in the context of the cultures of Asia. Hoi An, Viet Nam: UNESCO

[4] Kong, L. \& Yeoh, B., (1994). Urban Conservation in Singapore: a Survey of State Policies and Popular Attitudes. Urban Studies 1 (2)

[5] Ahmad, A. G. (1993). Conservation of British Colonial Buildings built between 1800 and 1930 in Malaysia. PhD. University of Sheffield 
[6] Dale, O. J. (1999). Urban Planning in Singapore; the transformation of a city. Kuala Lumpur: Oxford University Press

[7] Perry, M., Kong, L. and Yeoh, B. (1997). Singapore- A Developmental City State. England: John Wiley \& Sons Ltd

[8] Martokusumo, W. (2002). Urban Heritage Conservation: Experiences in Bandung and Jakarta. In: Nas, P. J. M. (ed.) The Indonesian Town Revisited. Singapore: LIT-Verlag-Institute of Asian Studies, pp. 374-389

[9] Hong Kong Urban Renewal Authority (2010). Urban Renewal Strategy (URS). Available at: www.devb-plb.gov.hk/eng/policy/urs.htm

[10] Idid, S. Z. A. (1996). Pemeliharaan Warisan Rupa Bandar (Conservation of the Heritage Townscape) Kuala Lumpur: Badan Warisan Malaysia (Heritage Malaysia Trust)

[11] Fee, C. (n.d). Conserving traditional values in urban development. Kuala Lumpur: Badan Warisan Malaysia (Heritage Malaysia Trust)

[12] HBP USM (2010). Extraction of the Antiquities Act 1976 (Government of Malaysia). [Online]. Available at: http://www.hbp.usm.my/conservation/ laws/antiquities\%20act.html

[13] Ahmad, A. G. (2005). National Heritage Act 2005, Malaysia. HBP USM. Available at: http://www.hbp.usm.my/conservation/laws/ nationalheritageact.htm

[14] Parliament of Malaysia (2005). National Heritage Bill

[15] UNESCO (2010). Melaka and George Town, Historic Cities of the Straits of Malacca. UNESCO.org

[16] Lee, L. M., Lim, Y. M. and Nor'Aini, Y. (2008). Strategies for urban conservation: A case example of George Town, Penang. Habitat International 32 (3), pp. 293-304

[17] Belinda, Y. (2006). Reclaiming Cultural Heritage in Singapore. Urban Affairs Review 41 (6), pp. 830-854 